\title{
Kinetic and mechanism of oxidation of chromium (III)-nicotinate complex by periodate
}

\author{
Michel F. Abdel-Messih", Zeinab M. Abou-Gamra, Hesham A. Medien and Mahmoud Abd Elnaby Wafi \\ Department of Chemistry, Faculty of Science, Ain Shams University, Abbassia, 11566, Cairo, Egypt
}

ARTICLE INFO

Article history:

Received 13 April 2017

Accepted 24 July 2017

Keywords:

Kinetics;

Oxidation;

Chromium (III)-nic complex;

Periodate.

\begin{abstract}
A B S T R A C T
The kinetics of oxidation of $\left[\mathrm{Cr} \text { III }(\text { nic })\left(\mathrm{H}_{2} \mathrm{O}\right)_{2}\right]^{+}$(nic $=$nicotinate) by $\mathrm{IO}_{4}{ }^{-}$to $\mathrm{Cr}(\mathrm{VI})$ have been studied spectrophotometrically. The reactions exhibited biphasic kinetic behavior. This has been interpreted in terms of consecutive twostep reactions. The first faster step involved the oxidation of the $\mathrm{Cr}$ (III) complex to a $\mathrm{Cr}$ (IV) species. The second slower reaction involved the oxidation of $\mathrm{Cr}$ (IV) species to $\mathrm{Cr}(\mathrm{V})$. Both steps exhibited first order dependence on the initial $[\mathrm{Cr}$ (III)] as well as first order dependence on $\left[\mathrm{IO}_{4}{ }^{-}\right]$. The rates of both processes increased with increasing $\mathrm{pH}$ due to the deprotonation equilibria of the complex. The experimental rate law was consistent with a mechanism in which the deprotonated form $\left[\mathrm{Cr}\right.$ III $\left.(\mathrm{nic})\left(\mathrm{H}_{2} \mathrm{O}\right)(\mathrm{OH})\right]$ was more reactive than the conjugated acid. It was proposed that electron transfer proceeds through an innersphere mechanism via coordination of $\mathrm{IO}_{4}{ }^{-}$to chromium (III). Thermodynamic activation parameters were calculated using the transition state theory equation.
\end{abstract}

\section{Introduction}

Oxidation of complexes by periodate have received some attention in recent years ${ }^{[1-3]}$. They have been reported to play an important role in biological determinants ${ }^{[4,5]}$. They are used to degrade carbohydrate determinants in proteins without altering protein or lipid epitopes [6]. Alpha amino acids in protein can be determined by measuring the liberated ammonia through the oxidation with periodate in carbonate medium ${ }^{[5]}$. Oxidations of inorganic substrates by periodate are reported to proceed via an inner sphere mechanism ${ }^{[7,8]}$. The oxidation of a number of chromium (III) complexes has been reported in order to support this mechanism. The kinetics, in each case, is interpreted in terms of formation of a precursor complex followed by a slower intramolecular electron transfer step. It is often suggested that substitution occurs on the chromium(III) reactive species. This seems to be unlikely, even in the presence of the labializing $\mathrm{OH}^{-}$ligand, since chromium(III) complexes, generally, are known to be inert, the oxidation of these inert complexes occurred through bridging of $\mathrm{IO}_{4}{ }^{-}$with the hydroxo group acting as a bridging ligand ${ }^{[9-12]}$. The oxidation of the labile complexes occurred through substitution of the coordinated $\mathrm{H}_{2} \mathrm{O}$ by $\mathrm{IO}_{4}^{-}$as a ligand ${ }^{[12-14]}$. Sometimes the oxidation occurred through coordination of periodate by the two ways together ${ }^{[3,15-19]}$, thus periodate has the

* Corresponding author.

E-mail address: michelfahmy@ sci.asu.edu.eg ability of oxidizing both labile and inert complexes that possess one bridging ligand ${ }^{[7,20,21]}$. The present work aimed to study the kinetics of oxidation of chromium(III)-nicotinate complex by periodate and the change of its chemical formula in an aqueous medium.

\section{Materials and methods}

All reagents were of pure grade and were used without further purification. A stock solution of nicotinic acid was prepared by dissolving accurate weight of nicotinic acid in dilute solution of $\mathrm{NaOH}$. Chromium (III)nicotinate complex was prepared by leaving the mixture of $\mathrm{Cr}\left(\mathrm{NO}_{3}\right)_{3}$ with excess nicotinic acid solution for 48 hour at $\mathrm{pH}$ range 4-4.5. The purity of $\mathrm{Cr}$ III complex was confirmed by its UV- Vis absorption spectrum, this complex showing two peaks at 575 and $420 \mathrm{~nm}$. $\mathrm{NaClO}_{4}$ of known concentration was used to adjust the ionic strength. $\mathrm{NaOH}$ and $\mathrm{HCl}$ solutions were used to adjust the $\mathrm{pH}$ of the reaction mixture.

\section{Kinetic Measurements}

The UV-Visible absorption spectra of the products of oxidation of $\mathrm{Cr}$ (III)-nicotinate complex by periodate were followed spectrophotometrically using a PG-T $92^{+}$ UV-Vis spectrophotometer equipped with a waterjacketed cell holder. Solutions of periodate and the complex at the required $\mathrm{pH}$ were thermostated at the required temperature for $20 \mathrm{~min}$, then mixed and quickly transferred to an absorption cell. The oxidation rates were measured by monitoring the absorption of $\mathrm{Cr}^{\mathrm{VI}}$ at $346 \mathrm{~nm}$. The $\mathrm{pH}$ of the reaction mixture was measured 
using a Griffin $\mathrm{pH}$ meter fitted with a combined glass calomel electrode. The ionic strength of the reaction was adjusted using $\mathrm{NaClO}_{4}$ solution. Pseudo first order conditions were maintained in all runs by using a large excess of $\mathrm{IO}_{4}{ }^{-}$(more than 10-fold).

\section{Results and discussion}

During the oxidation of the $\mathrm{Cr}$ (III) -nicotinate complex in aqueous solutions, the violet color complex changed gradually to yellow, Fig. 1. The original two absorption peaks, of the complex at 575 and 420nm were replaced by a single peak at $346 \mathrm{~nm}$; the peak position being dependent on the $\mathrm{pH}$ of the reaction ${ }^{[22-24]}$. Presence of an isosbestic point at $510 \mathrm{~nm}$ in the absorption spectra was taken as the criterion for the presence of two absorbing species in equilibrium.

The kinetics of oxidation of $\left[\mathrm{CrIII}(\text { nic })\left(\mathrm{H}_{2} \mathrm{O}\right)_{2}\right]^{+}$by periodate were studied at different reaction conditions, namely, $2.4-5.8 \mathrm{pH}$ range, $0.01-0.11 \mathrm{~mol} \mathrm{dm}^{-3}$ ionic strength, $\quad(0.2-2.0) \times 10^{-3} \mathrm{~mol} \mathrm{dm}{ }^{-3}$ periodate concentration range, $(1-15) \times 10^{-4}$ mol.dm ${ }^{-3}$ complex concentration range, and at $35.0-50.0^{\circ} \mathrm{C}$.

The kinetics of the reaction were studied under pseudofirst order condition with the concentration of periodate greatly exceeding that of the chromium (III) complex. The plots of $\ln \left(\mathrm{A}_{\infty}-\mathrm{A}_{\mathrm{t}}\right)$ versus time for more than $85 \%$ of the reaction progress (Fig. 2) reveal two linear stages, i.e. a faster reaction is followed by a slower one.

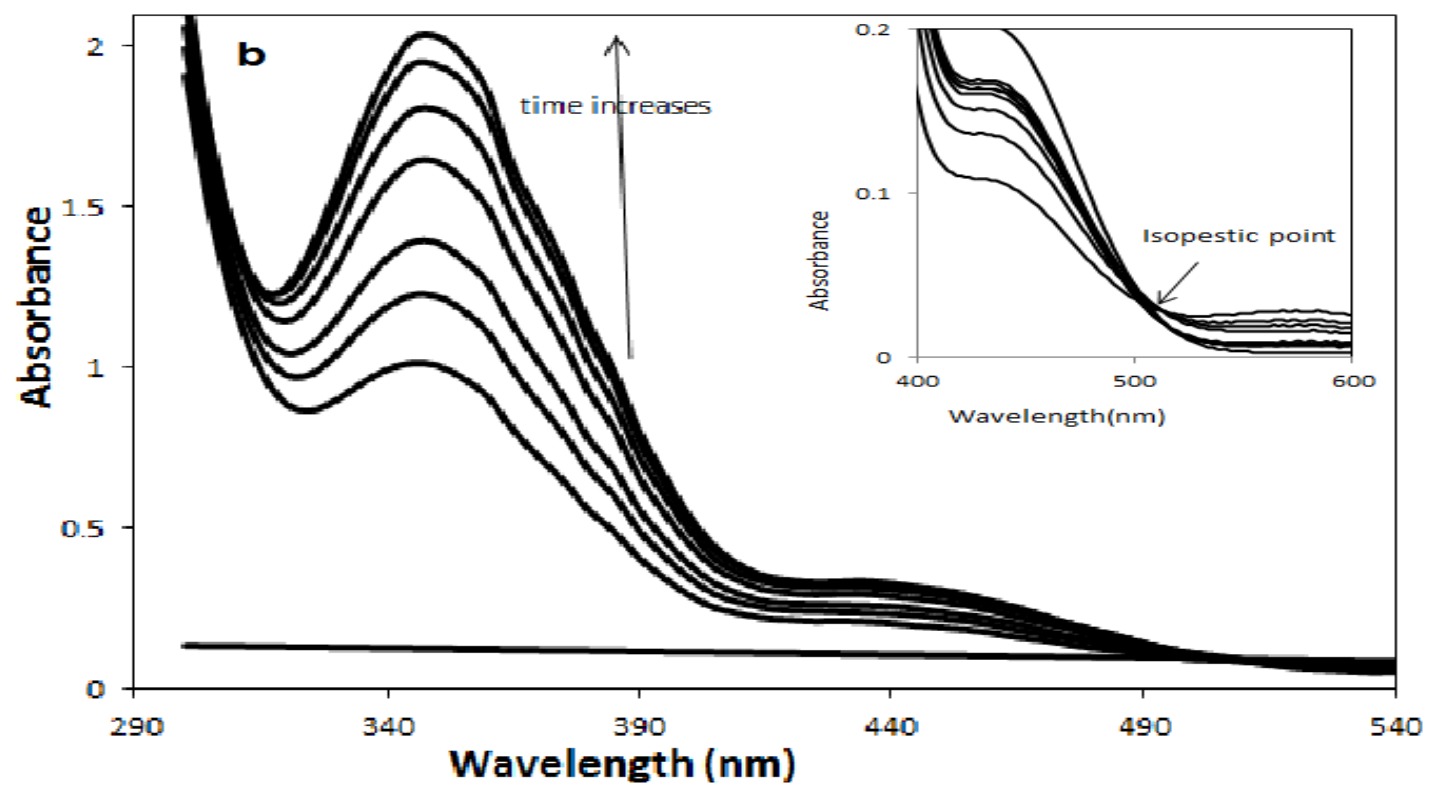

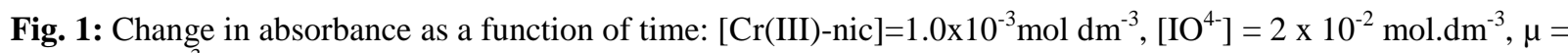
0.02 mol. $. \mathrm{dm}^{-3}, \mathrm{pH}=3.2$, Temp $=35^{\circ} \mathrm{C}$.

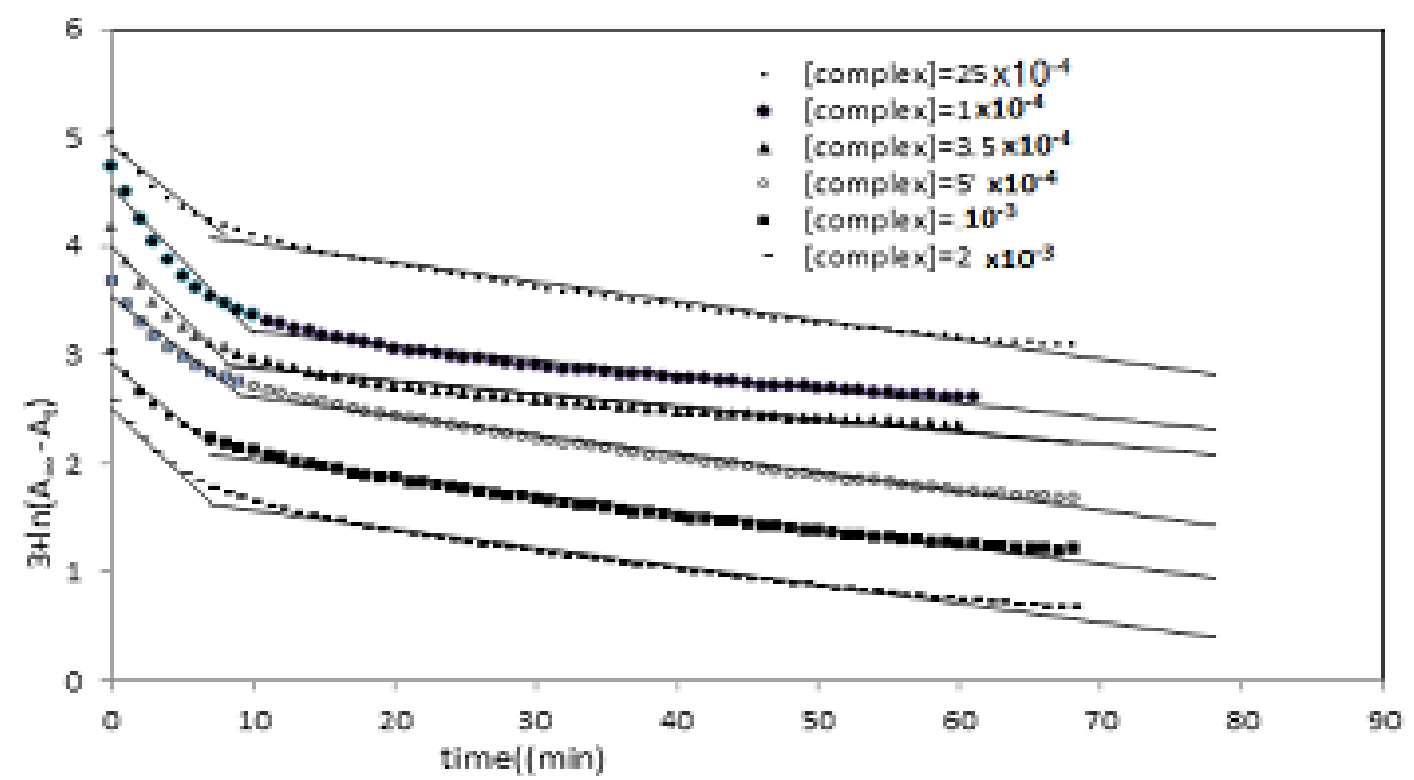

Fig. 2: First order plots for the reaction of $\mathrm{Cr}(\mathrm{III})$-nicotinate complex with sodium periodate at different complex concentrations. $\left[\mathrm{KIO}_{4}\right]=10^{-2} \mathrm{~mol} \mathrm{dm}^{-3}, \mu=0.11 \mathrm{~mol} \mathrm{dm}^{-3}, \mathrm{Temp}=35^{\circ} \mathrm{C}, \mathrm{pH}=3.5$. 
The observed rate constants $k_{\text {lobs }}$ and $k_{2 \text { obs }}$ were obtained by fitting the kinetic data $\ln \left(\mathrm{A}_{\infty}-\mathrm{A}_{\mathrm{t}}\right)$ versus $t$ using the logarithmic form of a biexponential equation (Eq. (1)). The rate constants $k_{\text {lobs }}$ and $k_{2 o b s}$ are represents by $1 / \mathrm{t}_{1}$ and $1 / t_{2}$ respectively in Eq. (1) ${ }^{[25]}$.

$$
Y=Y_{0}+e^{-x / t_{1}}+e^{-x / t_{2}}
$$

The rate constants $k_{\text {lobs }}$ and $k_{2 o b s}$ obtained from the curve fitting simulation are similar to those obtained from semi-log plots. From linear parts of the plot of $\ln \left(\mathrm{A}_{\infty}-\mathrm{A}_{\mathrm{t}}\right)$ versus time, $k_{\text {lobs }}$ and $k_{2 o b s}$ were calculated from the slopes as listed in Table 1.

The linear parallel variation of $\log k_{\text {lobs }}$ and $\log k_{2 o b s}$ with the $\mathrm{pH}$ of the reaction medium (Fig. 3) suggests a single reaction proceeding with two rate constants characteristic of slow and fast stages of the reaction.

Table (1): Kinetic data of oxidation of $\mathrm{Cr}(\mathrm{III})$-nicotinate complex by periodate .

\begin{tabular}{|c|c|c|c|c|c|c|}
\hline [complex] x $10^{4}$ & {$\left[\mathrm{NaIO}_{4}\right] \times 10^{2}$} & Temp & \multirow{2}{*}{ pH } & \multirow{2}{*}{$\frac{\mu}{\text { mol.dm }^{-3}}$} & \multirow{2}{*}{$\frac{\mathrm{k}_{\text {1obs }} \times 10^{3}}{\mathrm{~s}^{-1}}$} & \multirow{2}{*}{$\frac{\mathrm{k}_{2 \mathrm{obs}} \times 10^{3}}{\mathrm{~s}^{-1}}$} \\
\hline mol.dm ${ }^{-3}$ & mol.dm ${ }^{-3}$ & ${ }^{\circ} \mathrm{C}$ & & & & \\
\hline 1 & 1 & 35 & 3.5 & 0.11 & 2.309 & 0.236 \\
\hline 3.5 & & & & & 2.196 & 0.206 \\
\hline 5 & & & & & 2.077 & 0.312 \\
\hline 10 & & & & & 2.022 & 0.223 \\
\hline 20 & & & & & 2.031 & 0.296 \\
\hline 25 & & & & & 2.064 & 0.288 \\
\hline 5 & 0.25 & 35 & 3.5 & 0.11 & 1.007 & 0.152 \\
\hline 7.5 & & & & & 1.169 & 0.165 \\
\hline 8.75 & & & & & 1.181 & 0.126 \\
\hline 10 & & & & & 1.311 & 0.158 \\
\hline 15 & & & & & 1.431 & 0.165 \\
\hline \multirow[t]{6}{*}{10} & 0.4 & 35 & 3.5 & 0.11 & 0.603 & 0.046 \\
\hline & 0.5 & & & & 1.379 & 0.223 \\
\hline & 0.8 & & & & 1.697 & 0.358 \\
\hline & 1 & & & & 2.055 & 0.379 \\
\hline & 1.5 & & & & 2.257 & 0.806 \\
\hline & 2 & & & & 2.748 & 1.206 \\
\hline \multirow[t]{4}{*}{10} & 1 & 35 & 3.5 & 0.01 & 2.701 & 0.415 \\
\hline & & & & 0.02 & 2.608 & 0.382 \\
\hline & & & & 0.05 & 2.759 & 0.445 \\
\hline & & & & 0.11 & 2.572 & 0.367 \\
\hline \multirow[t]{6}{*}{10} & 1 & 35 & 2.4 & 0.11 & 0.223 & 0.091 \\
\hline & & & 2.7 & & 0.336 & 0.160 \\
\hline & & & 3.5 & & 1.896 & 0.435 \\
\hline & & & 4.5 & & 2.279 & 0.636 \\
\hline & & & 5 & & 2.850 & 0.962 \\
\hline & & & 5.8 & & 3.429 & 1.061 \\
\hline \multirow[t]{6}{*}{10} & 1 & 40 & 2.6 & 0.11 & 0.316 & 0.126 \\
\hline & & & 2.8 & & 0.711 & 0.333 \\
\hline & & & 3.5 & & 1.744 & 0.438 \\
\hline & & & 4.5 & & 2.062 & 0.546 \\
\hline & & & 5 & & 2.349 & 0.750 \\
\hline & & & 5.8 & & 2.952 & 1.130 \\
\hline \multirow[t]{6}{*}{10} & 1 & 45 & 2.5 & 0.11 & 0.266 & 0.119 \\
\hline & & & 2.8 & & 0.848 & 0.480 \\
\hline & & & 3.5 & & 1.835 & 0.590 \\
\hline & & & 4.5 & & 2.072 & 0.868 \\
\hline & & & 5 & & 2.480 & 1.486 \\
\hline & & & 5.8 & & 3.266 & 1.642 \\
\hline \multirow[t]{6}{*}{10} & 1 & 50 & 2.7 & 0.11 & 0.516 & 0.266 \\
\hline & & & 3.1 & & 1.518 & 0.365 \\
\hline & & & 3.5 & & 1.736 & 0.660 \\
\hline & & & 4.5 & & 1.990 & 0.813 \\
\hline & & & 5 & & 2.572 & 0.941 \\
\hline & & & 5.8 & & 3.257 & 1.399 \\
\hline
\end{tabular}



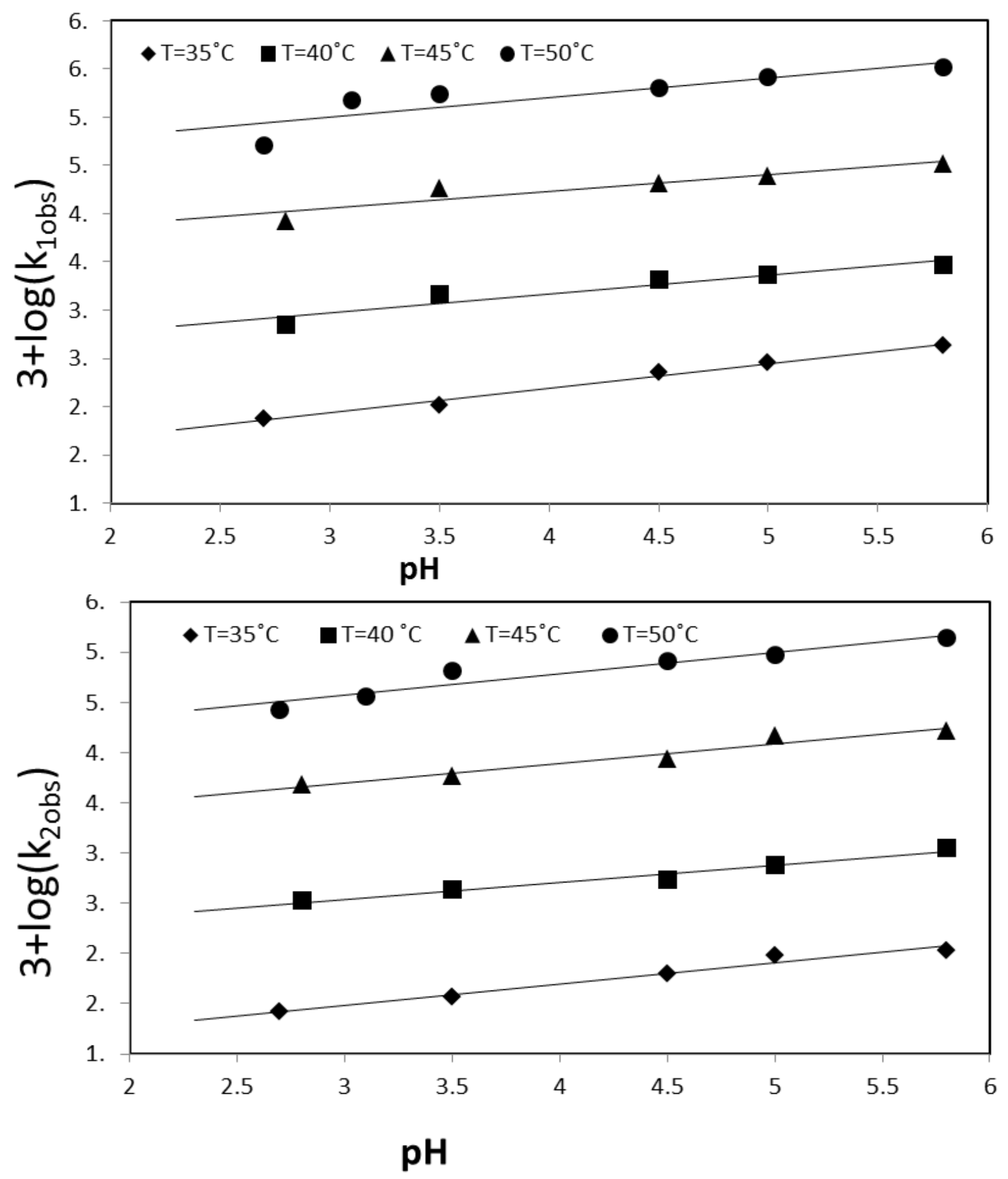

Fig. 3: Variation of $\log \mathrm{k}_{1 \text { obs }}$ and $\log \mathrm{k}_{2 \mathrm{obs}}$ with $\mathrm{pH},[\mathrm{Cr}(\mathrm{III})-\mathrm{nic}]=10^{-3} \mathrm{~mol} \mathrm{dm}^{-3},\left[\mathrm{KIO}_{4}\right]=10^{-2} \mathrm{~mol} \mathrm{dm}^{-3}$ and Temp $=35^{\circ} \mathrm{C}$.

The linear change of $k_{\text {lobs }}$ versus $k_{2 o b s}$, (Fig. 4), also indicates a single reaction with different rate constants. The constancy of the observed rate constants $\left(k_{\text {lobs }}\right.$ and $k_{2 o b s}$ ) over the whole $\mathrm{Cr}(\mathrm{III})$ complex concentrations agrees well with a first order kinetics with respect to the complex concentration (Table 1) which can be represented by Eq.(2).

$$
\mathrm{d}\left[\mathrm{Cr}^{\mathrm{VI}}\right] / \mathrm{dt}=\mathrm{k}_{\mathrm{obs}}\left[\mathrm{Cr}^{\mathrm{III}}\right]_{\mathrm{T}}
$$

Where $\left[\mathrm{Cr}^{\mathrm{III}}\right]_{\mathrm{t}}$ represents the total chromium(III) concentration.

The variation of $k_{\text {lobs }}$ and $k_{2 o b s}$ with periodate concentration is shown in Table 1. It is obvious from these results that $k_{\text {lobs }}$ and $k_{2 o b s}$ do not vary linearly in this study. Indeed, the variation with periodate is small, indicating high association between the two reactants. It is also clear from the results in Table 1 that under constant reaction conditions, plots of $1 / k_{\text {obs }}$ versus $1 / \mathrm{IO}_{4}^{-}$ are linear with intercepts and slopes as shown in Fig. 5. 

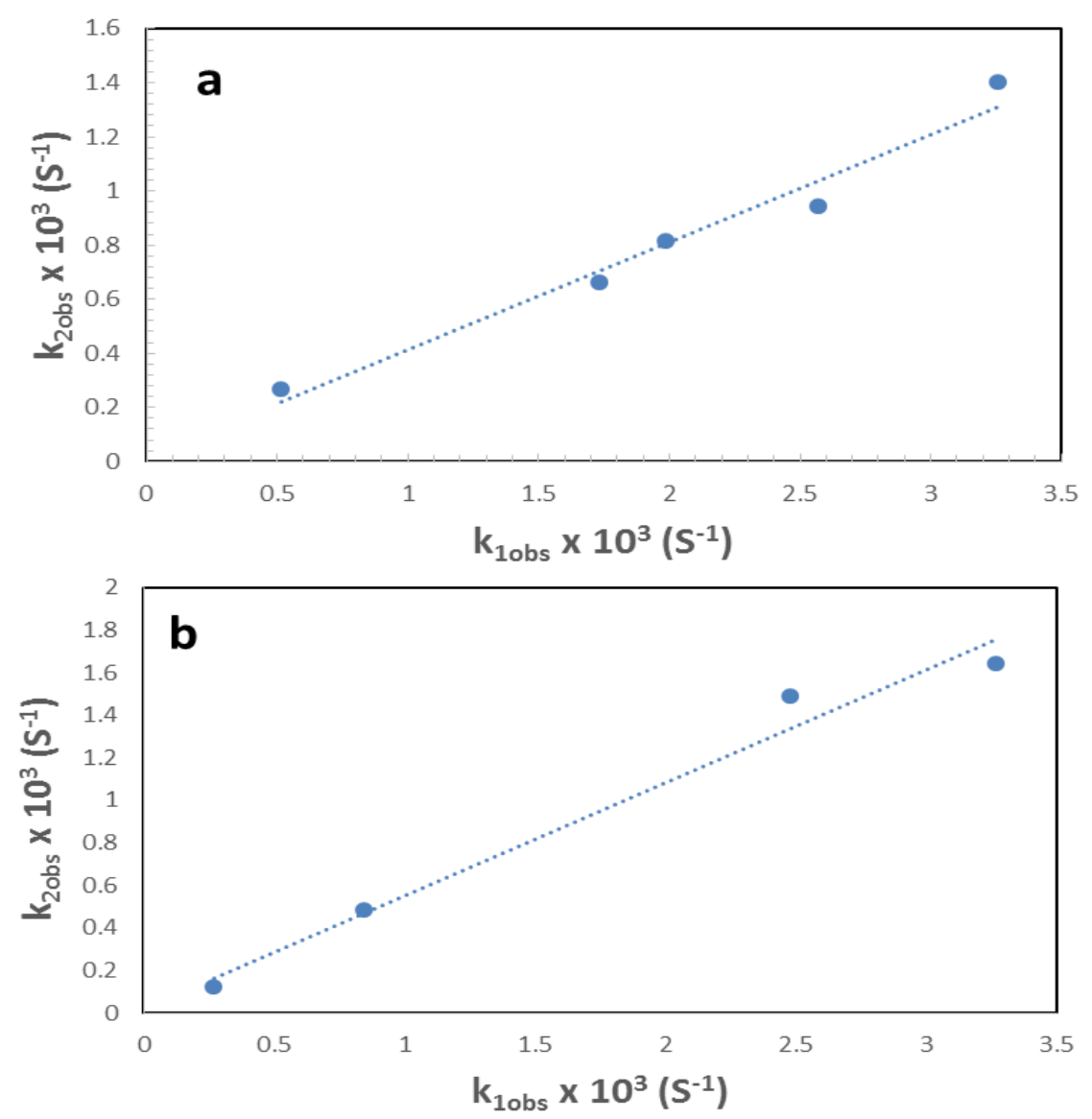

Fig. 4: Variation of $\mathrm{k}_{1 \text { obs }}$ with $\mathrm{k}_{2 \mathrm{obs}},[\mathrm{Cr}(\mathrm{III})-\mathrm{nic}]=10^{-3} \mathrm{~mol} \mathrm{dm}^{-3},\left[\mathrm{KIO}_{4}\right]=10^{-2} \mathrm{~mol} \mathrm{dm}^{3}$, at different $\mathrm{pH}$, a-temp $=$ $45^{\circ} \mathrm{C}$ and $\mathbf{b}$ - temp $=50^{\circ} \mathrm{C}$.
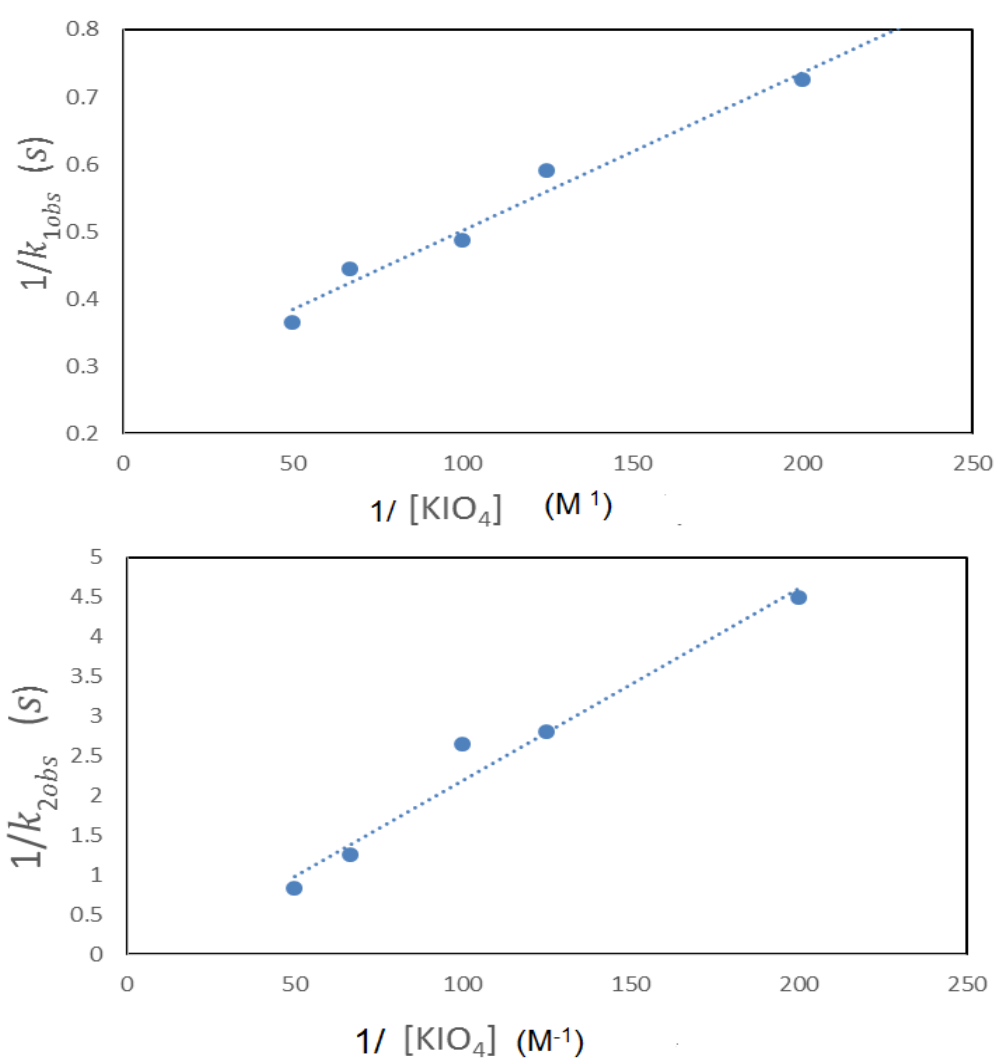

Fig. 5: The variation of $1 / \mathrm{k}_{1 \text { obs }}$ and $1 / \mathrm{k}_{2 \text { obs }}$ with $1 /\left[\mathrm{KIO}_{4}\right] . \mathrm{pH}=5.5$, Temp $=35^{\circ} \mathrm{C},[\mathrm{Cr}(\mathrm{III})-\mathrm{nic}]=10^{-3} \mathrm{~mol} \mathrm{dm}{ }^{-3}$. 
The dependence of $k_{o b s}$ values on $\mathrm{IO}_{4}^{-}$concentration can be represented by Eq. (3), at constant reaction conditions.

$$
k_{o b s}=a\left[I_{4}^{-}\right] /\left\{b+\mathrm{c}\left[\mathrm{IO}_{4}^{-}\right]\right\}
$$

Periodate ion is known to be involved in complex equilibria in aqueous solution ${ }^{[14]}$. Under the reaction conditions, the most likely periodate species are $\mathrm{IO}_{4}{ }^{-}$.

The effect of hydrogen ion concentration $\left[\mathrm{H}^{+}\right]$on the reaction rate was investigated over the $\mathrm{pH}$ range (2.4$5.8)$ at different temperatures. The values of $k_{\text {lobs }}$ and $k_{2 o b s,}$ (Table 1) indicate that the reaction rate decreases with increasing $\left[\mathrm{H}^{+}\right]$value (Fig. 6).

The $\quad\left[\mathrm{CrIII}(\mathrm{nic})_{2}\left(\mathrm{H}_{2} \mathrm{O}\right)_{2}\right]^{+} \quad$ complex undergoes deprotonation-protonation equilibrium as shown in Eq. (4). The finding that the reaction rate increases with increasing the $\mathrm{pH}$ indicates that the deprotonated form of the $\mathrm{Cr}(\mathrm{III})$ complex is the most reactive form of the complex. In almost the all oxidation reactions of $\mathrm{Cr}(\mathrm{III})$ species with $\mathrm{IO}_{4}^{-}$, the deprotonated forms are more readily oxidized ${ }^{[3,9]}$, this support the involvement of the deprotonated form of chromium(III) complex in the rate determining step in the present study.

$$
\left[\mathrm{Cr}^{\mathrm{II}}(\text { nic) })_{2}\left(\mathrm{H}_{2} \mathrm{O}\right)_{2}\right]^{2+} \stackrel{\mathrm{K}_{1}}{\longleftrightarrow}\left[(\text { nic })_{2} \mathrm{Cr}^{\mathrm{III}}\left(\mathrm{H}_{2} \mathrm{O}\right)(\mathrm{OH})\right]^{+}+\mathrm{H}^{+}
$$

The mechanism of oxidation of $\left[\mathrm{CrIII}(\mathrm{nic})_{2}\left(\mathrm{H}_{2} \mathrm{O}\right)_{2}\right]^{+}$by $\mathrm{IO}_{4}^{-}$may be represented by the reaction sequence in Eq. $(4,5,6,7)$. The reaction may proceed via one or two electron transfer, giving chromium (IV) or chromium $(\mathrm{V})$, respectively, in the rate determining step leading to chromium(VI) ${ }^{[25]}$. Two electron transfer is the most likely pathway.

$\left[(\text { nic) })_{2} \mathrm{Cr}^{\text {rII }}\left(\mathrm{H}_{2} \mathrm{O}\right)(\mathrm{OH})\right]^{+}+I_{4}^{-} \stackrel{\mathrm{K}_{2}}{\longrightarrow}\left[(\text { nic })_{2} \mathrm{Cr}^{\mathrm{III}}\left(\mathrm{H}_{2} \mathrm{O}\right)(\mathrm{OH})-\mathrm{OIO}_{3}\right]+\mathrm{H}_{2} \mathrm{O}$

$\left[(\text { nic) })_{2} \mathrm{Cr}^{\mathrm{II}}\left(\mathrm{H}_{2} \mathrm{O}\right)(\mathrm{OH})-\mathrm{OIO}_{3}\right] \stackrel{k^{e t}}{\longrightarrow}\left[(\text { nic })_{2} \mathrm{Cr}^{\mathrm{V}} \mathrm{O}\right]^{+}+\mathrm{IO}_{3}^{-}+\mathrm{H}_{2} \mathrm{O}+\mathrm{OH}^{-}(6)$

$\left[(\text { nic })_{2} \mathrm{Cr}^{V} \mathrm{O}\right]^{+}+\mathrm{IO}_{4}^{-} \rightarrow 2 \mathrm{Cr}^{V I}+\mathrm{IO}_{3}^{-}+2 n i c$
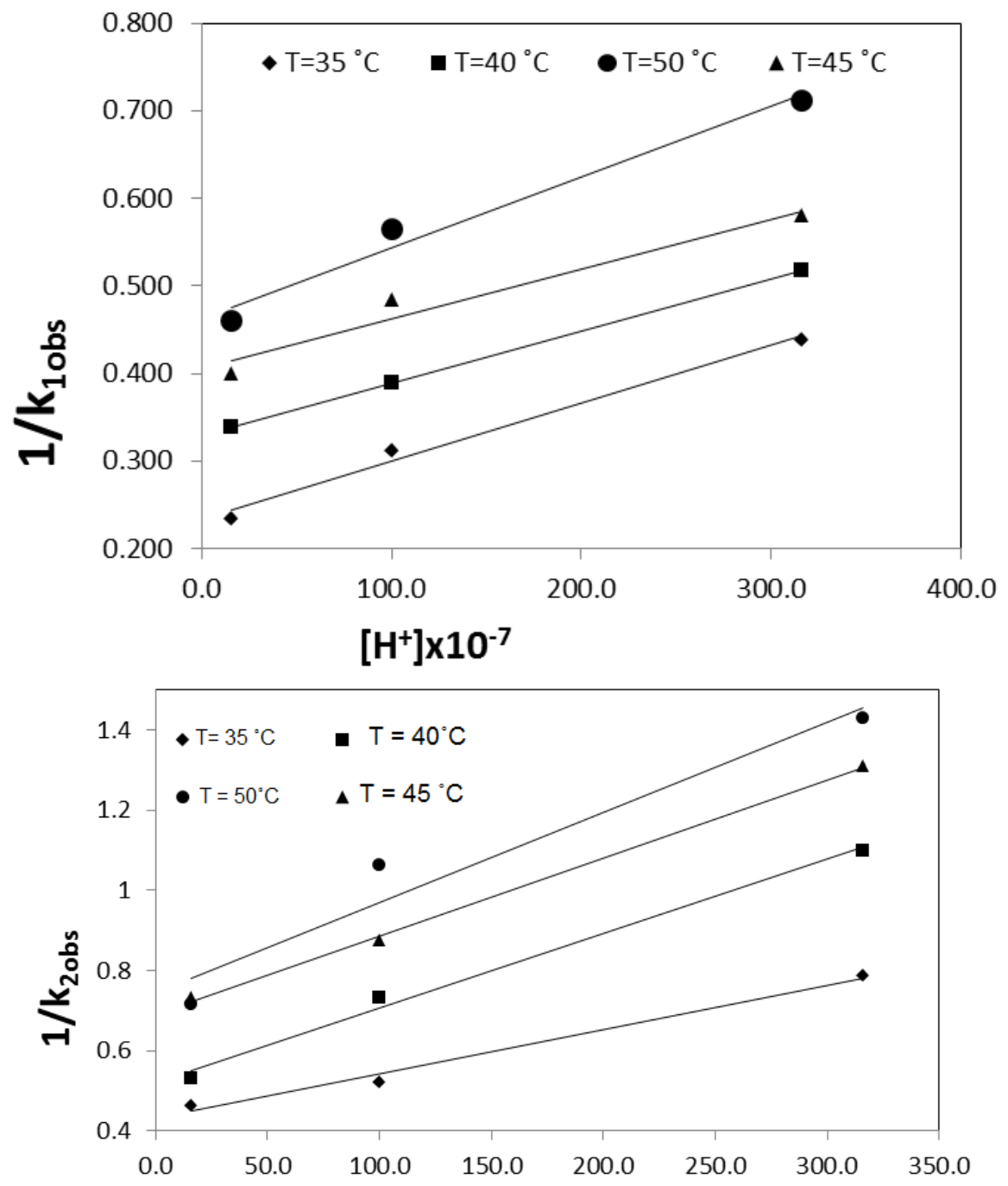

$\left[\mathrm{H}^{+}\right] \times 10^{-7}$

Fig. 6: The inverse dependence of $\mathrm{k}_{1 \mathrm{obs}}$ and $\mathrm{k}_{2 \mathrm{obs}}$ on the hydrogen ion concentration of at various temperature, $\left[\mathrm{KIO}_{4}\right]=10^{-2} \mathrm{~mol} \mathrm{dm}{ }^{-3},[\mathrm{Cr}(\mathrm{III})-\mathrm{nic}]=10^{-3} \mathrm{~mol} \mathrm{dm}^{-3}$. 
From the above mechanism, the rate is represented as:

$$
\begin{aligned}
& d\left[\mathrm{Cr}^{V I}\right] / d t=2 k^{e t} \quad\left[(\mathrm{nic})_{2}\left(\mathrm{H}_{2} \mathrm{O}\right) \quad \mathrm{Cr}^{\mathrm{III}}-\mathrm{OH}-\mathrm{IO}_{4}^{-}\right] \\
& \text {rate }=2 k^{e t} \quad \mathrm{~K}_{2}\left[(\mathrm{nic})_{2} \mathrm{Cr}^{\mathrm{II}}\left(\mathrm{H}_{2} \mathrm{O}\right) \mathrm{OH}\right]\left[\mathrm{IO}_{4}^{-}\right]
\end{aligned}
$$

If it is assumed that $[\mathrm{Cr}(\mathrm{III})]_{\mathrm{t}}$ represents all the chromium(III) species, then,

$$
\left[\mathrm{Cr}^{\text {III }}\right]_{T}=\left[\mathrm{Cr}^{\text {III }}(\text { nic })_{2}\left(\mathrm{H}_{2} \mathrm{O}\right)_{2}\right]^{2+}+\left[(\text { nic }){ }_{2} \mathrm{Cr}^{\mathrm{III}}\left(\mathrm{H}_{2} \mathrm{O}\right)(\mathrm{OH})\right]^{+}+\left[(\mathrm{nic})_{2} \mathrm{Cr}^{\mathrm{III}}\left(\mathrm{H}_{2} \mathrm{O}\right)(\mathrm{OH})-\mathrm{OIO}_{3}\right]
$$

Substituting for $\left[\mathrm{CrIII}(\text { nic })_{2}\left(\mathrm{H}_{2} \mathrm{O}\right)_{2}\right]^{2+}$ from Eq. (4) in Eq. (10) we obtain Eq. (11).

$$
\begin{aligned}
& {\left[\left[\mathrm{Cr}^{\text {III }}\right]_{T}=\left[\mathrm{Cr}^{\text {III }}(\text { nic) })_{2}\left(\mathrm{H}_{2} \mathrm{O}\right) \mathrm{OH}\right]^{2+}\left\{\left[H^{+}\right]+K_{1}+K_{1} K_{2}\left[\mathrm{IO}_{4}^{-}\right] / K_{1}\right\}\right.} \\
& {\left[\mathrm{Cr}^{\text {III }}(\text { nic) })_{2}\left(\mathrm{H}_{2} \mathrm{O}\right)_{2} \mathrm{OH}\right]^{2+}=\left[\mathrm{Cr}^{\text {III }}\right]_{T} /\left\{\left[H^{+}\right]+K_{1}+K_{1} K_{2}\left[I O_{4}^{-}\right] / K_{1}\right\}}
\end{aligned}
$$

Since the reaction is first order in $[\mathrm{Cr}(\mathrm{III})]_{\mathrm{t}} \mathrm{Eq}(2)$, the pseudo-first order rate constant, $k_{\text {obs }}$ is given by $\mathrm{Eq}(13)$.

$$
\begin{aligned}
& k_{o b s}=2 k^{e t} K_{1} K_{2}\left[I O_{4}^{-}\right] /\left\{\left[H^{+}\right]+K_{1}+\mathrm{K}_{1} \mathrm{~K}_{2}\left[\mathrm{IO}_{4}^{-}\right]\right\} \\
& \frac{1}{k_{o b s}}=\frac{1}{2 k^{e t}}+\left\{K_{1}+\left[H^{+}\right]\right\} \quad / 2 k^{e t} K_{1} K_{2}\left[I O_{4}^{-}\right]
\end{aligned}
$$

From Eq. (14) the intercept I1 and the slope S1 are given by Eq. (15) and (16), respectively.

$$
\begin{aligned}
& S=\left\{K_{1}+\left[H^{+}\right]\right\} \quad / 2 k^{e t} K_{1} K_{2} \\
& I=\frac{1}{2 k^{e t}}
\end{aligned}
$$

The values $\mathrm{k}^{\mathrm{et}}$ (rate constant for electron transfer steps) are obtained from Eq. (16) as $3.77 \times 10^{-3} \mathrm{~s}^{-1}$ and 2.67 $\mathrm{x} 10^{-3} \mathrm{~s}^{-1}$ at $35^{\circ} \mathrm{C}$. The effect of ionic strength on the oxidation rate was investigated as shown in Table 1. It is clear from these results that the values of $k_{\text {lobs }}$ and $k_{2 o b s}$ were unaffected when the ionic strength was varied at constant reaction conditions. This is consistent with the proposition that the reactive chromium(III) species is deprotonated form, attributed to the deprotonation of the complex. The effect of temperature on the oxidation rates was also studied and the results are shown in Table 1. The isokinetic relation supports a common mechanism for the oxidation of chromium(III) complexes, reported here, by periodate. This consists of a periodate ion coordination to the chromium(III) complexes in a step preceding the rate-determining intramolecular electron transfer within the precursor complex.

It is obvious from these results that $k_{\text {lobs }}$ and $k_{2 o b s}$ increase with increasing temperature. The enthalpy,
$\Delta \mathrm{H}^{*}$, and entropy, $\Delta \mathrm{S}^{*}$, of activation for the electron transfer process in the oxidation of $\left[\mathrm{CrIII}(\mathrm{nic})_{2}\left(\mathrm{H}_{2} \mathrm{O}\right)_{2}\right]^{+}$ by $\mathrm{IO}_{4}^{-}$was calculated using Eyring equation. The values of $\Delta \mathrm{H}^{*}$ and $\Delta \mathrm{S}^{*}$ associated with this process were obtained as 33.2, $44.6 \mathrm{~kJ} \mathrm{~mol}^{-1}$ and -158, -112, $\mathrm{J} \mathrm{mol}^{-1} \mathrm{~K}^{-}$ ${ }^{1}$, for the faster and the slower steps $\left(k_{\text {lobs }}\right.$ and $\left.k_{2 o b s}\right)$, respectively.

Enthalpies and entropies of activation for the oxidation of some chromium (III) complexes by periodate were calculated related to intramolecular electron transfer steps (Table 2).

A plot of $\Delta \mathrm{H}^{*}$ versus $\Delta \mathrm{S}^{*}$ for these complexes is shown in Fig. 7, an excellent linear relationship was obtained.

The isokinetic relation supports a common mechanism for the oxidation of chromium(III) complexes, reported here, by periodate. This consists of a periodate ion coordination to the chromium(III) complexes in a step preceding the rate-determining intramolecular electron

\begin{tabular}{|c|c|c|c|c|}
\hline Complex & $\Delta \mathbf{H}^{*}\left(\mathrm{KJ} \mathrm{mol}^{-1}\right)$ & $-\Delta \mathbf{S}^{*}\left(\mathrm{JK}^{-1} \mathrm{~mol}^{-1}\right)$ & Ref & Figure 7 key \\
\hline$\left[\mathrm{Cr}^{\mathrm{III}}(\mathrm{HIDA})_{2}\left(\mathrm{H}_{2} \mathrm{O}\right)\right]$ & $12.3 \pm 1$ & $240.7 \pm 7$ & {$[26]$} & 1 \\
\hline$\left[\mathrm{Cr}^{\mathrm{III}}(\mathrm{HIDA})(\mathrm{Arg})\left(\mathrm{H}_{2} \mathrm{O}\right)_{2}\right]^{+}$ & $15.9 \pm 1.2$ & $227 \pm 5$ & [27] & 2 \\
\hline$\left[\mathrm{Cr}^{\mathrm{III}}(\mathrm{DPA})(\mathrm{OX})\left(\mathrm{H}_{2} \mathrm{O}\right)\right]^{-}$ & $31 \pm 2.6$ & $212 \pm 8.5$ & [28] & 3 \\
\hline$\left[\mathrm{Cr}^{\mathrm{III}}(\mathrm{HIDA})(\mathrm{VAL})\left(\mathrm{H}_{2} \mathrm{O}\right)\right]$ & $41.7 \pm 1.5$ & $162.5 \pm 3.3$ & [27] & 4 \\
\hline$\left[\mathrm{Cr}^{\mathrm{III}}(\mathrm{UD})\left(\mathrm{H}_{2} \mathrm{O}\right)_{3}\right]^{3+}$ & $37.8 \pm 3.1$ & $158.3 \pm 39.3$ & [29] & 5 \\
\hline$\left[\mathrm{Cr}^{\mathrm{III}}(\mathrm{UD})(\mathrm{Asp})\left(\mathrm{H}_{2} \mathrm{O}\right)_{3}\right]^{2+}$ & $59.5 \pm 9.2$ & $107 \pm 35.2$ & [29] & 6 \\
\hline$\left[\mathrm{Cr}^{\mathrm{III}}(\mathrm{NTA})(\mathrm{Asp})\left(\mathrm{H}_{2} \mathrm{O}\right)\right]^{-}$ & $64.6 \pm 8.5$ & $76 \pm 7.7$ & [30] & 7 \\
\hline$\left[\mathrm{Cr}^{\mathrm{III}}(\mathrm{TOH})\left(\mathrm{H}_{2} \mathrm{O}\right)\right]$ & $76 \pm 2.1$ & $38.7 \pm 7.1$ & [9] & 8 \\
\hline$\left[\mathrm{CrIII}(\mathrm{nic})_{2}\left(\mathrm{H}_{2} \mathrm{O}\right)_{2}\right]$ & 44.3 & 158 & This work & 9 \\
\hline$\left[\mathrm{CrIII}(\mathrm{nic})_{2}\left(\mathrm{H}_{2} \mathrm{O}\right)_{2}\right]$ & 33.2 & 112 & This work & 10 \\
\hline
\end{tabular}
transfer within the precursor complex.

\section{Conclusion}

The kinetics of oxidation of $\left[\mathrm{Cr}(\mathrm{nic})_{2}\left(\mathrm{H}_{2} \mathrm{O}\right)_{2}\right]^{+}$by periodate were investigate. The reaction was first-order in chromium-nicotinate complex, accelerated with increasing periodate concentration, $\mathrm{pH}$, temperature and ionic strength of the reaction medium. The oxidation of

Table (2): Enthalpies and Entropies of activation of the oxidation of some chromium(III) complexes by periodate. 


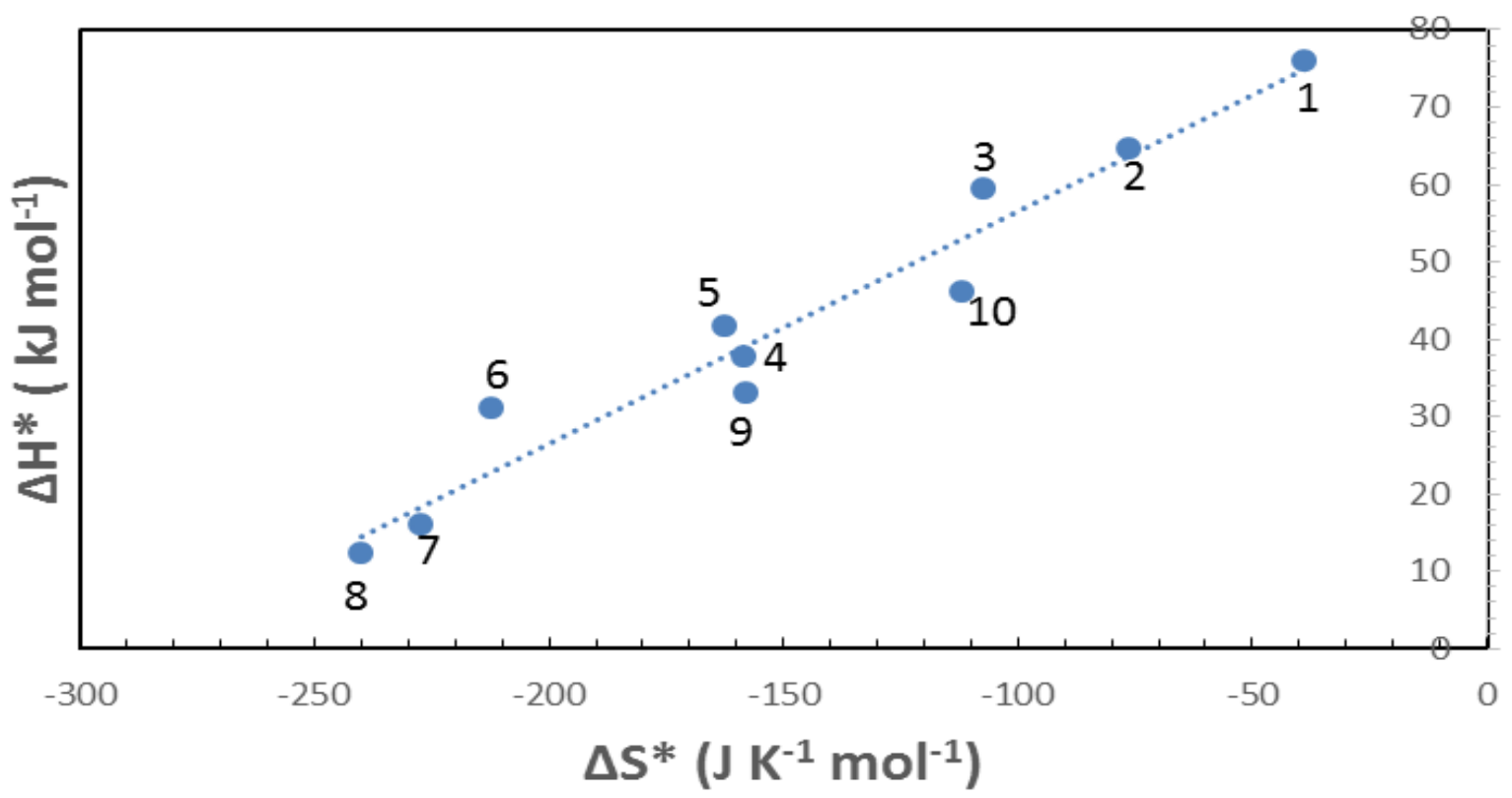

Fig. 7: Isokinetic plot for oxidation of chromium(III)-complexes by periodate, (1) $\left[\mathrm{Cr}^{\mathrm{III}}(\mathrm{HIDA})_{2}\left(\mathrm{H}_{2} \mathrm{O}\right)\right]$, (2) $\left[\mathrm{Cr}^{\text {III }}(\mathrm{HIDA})(\mathrm{Arg})\left(\mathrm{H}_{2} \mathrm{O}\right)_{2}\right]^{+}$, (3) $\left[\mathrm{Cr}^{\text {III }}(\mathrm{DPA})(\mathrm{OX})\left(\mathrm{H}_{2} \mathrm{O}\right)\right]^{-}$, (4) $\left[\mathrm{Cr}^{\text {IIII }}(\mathrm{HIDA})(\mathrm{VAL})\left(\mathrm{H}_{2} \mathrm{O}\right)\right],(\mathbf{5})\left[\mathrm{Cr}^{\mathrm{III}}(\mathrm{UD})\left(\mathrm{H}_{2} \mathrm{O}\right)_{3}\right]^{3+}$, (6) $\left[\mathrm{Cr}^{\text {III }}(\mathrm{UD})(\mathrm{Asp})\left(\mathrm{H}_{2} \mathrm{O}\right)_{3}\right]^{2+}$, (7) $\left[\mathrm{Cr}^{\mathrm{III}}(\mathrm{NTA})(\mathrm{Asp})\left(\mathrm{H}_{2} \mathrm{O}\right)\right]^{-}$, (8) $\left[\mathrm{Cr}^{\text {III }}(\mathrm{TOH})\left(\mathrm{H}_{2} \mathrm{O}\right)\right]$ and $(\mathbf{9 , 1 0})\left[\mathrm{CrIII}(\mathrm{nic})_{2}\left(\mathrm{H}_{2} \mathrm{O}\right)_{2}\right]$ this work.

$\left[\mathrm{Cr}(\text { nic })_{2}\left(\mathrm{H}_{2} \mathrm{O}\right)_{2}\right]^{+}$by periodate is assigned an innersphere mechanism. A common mechanism for the oxidation of ternary chromium(III) complexes by periodate is proposed and is supported by the excellent isokinetic relationship between $\Delta \mathrm{H}^{*}$ and $\Delta \mathrm{S}^{*}$ values for these reaction.

\section{References}

1) Abdel-Khalek, A. A., Hassan, E. S. and Mohamed, R. A. (2008). Mechanism of electron transfer reactions of ternary nitrilotriacetato cobaltate (II) complexes involving maleate and tartarate by periodate. Journal of Coordination Chemistry, 61(2):152-166.

2) Naik, R. M., Srivastava, A., Tiwari, A. K., Yadav, S. B. S. and Verma, A. K. (2007). Kinetic and mechanistic studies of oxidation of amine-Npolycarboxylates complexes of cobalt (II) by periodate ions in aqueous medium. Journal of the Iranian Chemical Society, 4(1):63-71.

3) Sulfab, Y. and Al-Jallal, N. A. (2004). Innersphere oxidation of cis-diaquabis (oxalato) chromate (III) by periodate in aqueous weakly acidic solutions. Transition metal chemistry, 29(2):216220.

4) Josiane, M., Toloti, C., Crisiti, D. B., Elias, Z. A. and Santos, M. L. (2005). Determination of glucose and fructose in syrup. Analyt Chim Acta, 531:279-284.

5) Slyke, D. D. V., Hiller, A., Macfadyen, D. A. and Hastings, A. B. (1994). Oxidation of Alpha-amino acid by periodate in carbonate medium. J Biol Chem, 133:287-293.
6) Carneiro, J. M. T., Dias, A. C. B., Zagatto, E. A. G. and Santos J. L. M. (2005). An improved sampling approach in multi-pumping flow systems applied to the spectrophotometric determination of glucose and fructose in syrups. Analytica chimica acta, 531(2):279-284.

7) Sulfab, Y. (1976). Kinetics and mechanism of oxidation of hexacyanoferrate (II) by periodate ions. Journal of Inorganic and Nuclear Chemistry, 38(12):2271-2274.

8) Sulfab, Y. and Abu-Shady, A. (1977). Kinetics and mechanism of oxidation of vanadium (IV) by periodate in aqueous acidic solutions. Inorganica Chimica Acta, 21:115-118.

9) Abdel-Khalek, A. A. and Elsemongy, M. M. (1988). Kinetics of the Oxidation of $[\mathrm{N}-(2-$ Hydroxyethyl) ethylenediamine- $\mathrm{N}, \mathrm{N}^{\prime}, \mathrm{N}^{\prime}$-triacetato] chromium (III) by Periodate. Bulletin of the Chemical Society of Japan, 61(12):4407-4410.

10) Al-Jallal, N. A. and Sulfab, Y. (1983). Kinetics of the oxidation of aquaethylenediaminetetraacetatochromium (III) by periodate. Transition Metal Chemistry, 8(1):51-53.

11) El-Eziri, F. R. and Sulfab, Y. (1977). Oxidation of hexaaquoiron (II) by periodate in aqueous acidic solution. Inorganica Chimica Acta, 25:15-20.

12) Kassim, A. Y. and Sulfab, Y. (1981). Kinetics and mechanism of the chromium (III)-periodate reaction. Inorganic Chemistry, 20(2):506-509.

13) Abdel-Khalek, A. A. and Sulfab, Y. (1981). Kinetics and mechanism of the oxidation of cobalt (II) aminopolycarboxylate complexes by periodate. Journal of Inorganic and Nuclear Chemistry, 43(12):3257-3262. 
14) Hussein, M. A., Abdel-Khalek, A. A. and Sulfab, Y. (1983). Inner-sphere oxidation of diaqua (nitrilotriacetato) cobaltate (II) by periodate in acetate medium. Isokinetic relationship for the oxidation of (aminopolycarboxylato) cobalt (II) complexes by periodate. Journal of the Chemical Society, Dalton Transactions, 1983(2):317-321.

15) Abdel-Khalek, A. A. (1990). Kinetic studies on the oxidation of [N-phenylethylethylenediaminetri acetate] chromium (III) by periodate. Transition Metal Chemistry, 15(2):112-115.

16) Abdel-Khalek, A. A., Sayyah, E. -S. M. and Ewais, H. A. (1997). Kinetics and mechanism of oxidation of the chromium (III)-dl-valine complex/periodate reaction. Evidence for iron (II) catalysis. Transition Metal Chemistry, 22(4):375380.

17) Abdel-Khalek, A. A., Sayyah, E. -S. M. and Ewais, H. A. (1997). Kinetics and mechanism of oxidation of chromium (III)-1-arginine complex by periodate. Transition metal chemistry, 22(6):557560.

18) Ali, I. H. and Sulfab, Y. (2013). Kinetics and mechanism of oxidation of cis-diaquabis (glycinato) chromium (III) by periodate ion in aqueous solutions. Transition Metal Chemistry, 38(1):79-84.

19) Eltahir, S. B. and Sulfab, Y. (2014). Kinetics and mechanism of the two electron oxidation of cis$\left.\mathrm{CrIII}(\text { dipy })_{2}\left(\mathrm{H}_{2} \mathrm{O}\right)_{2}\right] 3+$ (dipy 5 2,20-dipyridyl) by periodate ion to cis-[CrV(dipy $\left.)_{2}(\mathrm{O})_{2}\right]+$ in aqueous acidic solutions, Transition Met Chem, 39:399-405.

20) Hussein, M. A. and Sulfab, Y. (1982). Kinetics of the oxidation of octacyanomolybdate (IV) by periodate in aqueous acid. Transition Metal Chemistry, 7(3):181-183.

21) Abou-Gamra, Z. M., Abdel-Messih, M. F., Anis, S. S. and Abdel-Khalek, E. H. (2013). Kinetic studies on the oxidation of diethylenetriaminepentaacetato chromium(III) by periodate, Egy. J. Pure \& Appl. Sci. 51:61-67.

22) Abdel-Khalek, A. A., Mohamed, A. A. and Ewais, H. A. (1999). Kinetics and mechanism of oxidation of the chromium (III)-DL-aspartic acid complex/periodate reaction. Evidence for iron (II) catalysis. Transition Metal Chemistry, 24(2):233238.
23) Ewais, H. A., Ahmed, S. A. and Abdel-Khalek, A. A. (2004). Kinetics and Mechanism of Oxidation of Chromium (III)-guanosine 5-Monophosphate Complex by Periodate. Journal of the Chinese Chemical Society, 51(4):713-718.

24) Ewais, H. A., Khaled, E. S. and Abdel-khalek, A. A. (2001). Kinetics and mechanism of oxidation of chromium (III)-L-glutamic acid complex by periodate. Indian journal of chemistry section A, 40(4):410-414.

25) Eljack, N. D. and Sulfab, Y. (2012). Kinetics of the biphasic oxidation of aquaethylenediaminetetraacetatochromate(III) and cis-diaquabis(oxalato)chromate(III) complexes by N-bromosuccinimide in aqueous solutions: Formation of long-lived chromium(IV) complexes, Polyhedron 44:28-33.

26) Ewais, H. A., Al-Otaibi, F. D. and Abdel-Khalek, A. A. (2006). Kinetics and mechanism of oxidation of iminodiacetatochromium (III) by periodate. Inorganic reaction mechanisms-gordon and breach science publishers then old city publishing-, 6(1):39.

27) Weaver, M. J. and Yee, E. L. (1980). Activation parameters for homogeneous outer-sphere electrontransfer reactions. Comparisons between selfexchange and cross reactions using Marcus' theory. Inorganic Chemistry, 19(7):1936-1945.

28) Ewais, H. A. and Ismail, I. M. I. (2013). Mechanism of electron transfer reaction of ternary dipicolinatochromium (III) complex involving oxalate as secondary ligand. Journal of Chemical Sciences, 125(5):1151-1159.

29) Khaled, E. S. (2007). Inner-Sphere Oxidation of Binary and Ternary Uridine Chromium (III) Complexes Involving Aspartate by Periodate. Inorganic reaction mechanisms-gordon and breach science publishers then old city publishing-, 6(3):247.

30) Ewais, H. A., Habib, M. A. and Elroby, S. A. (2010). Kinetics and mechanism of periodate oxidation of two ternary nitrilotriacetatochromium (III) complexes involving histidine and aspartate coligands. Transition Metal Chemistry, 35(1):73-80. 